\title{
An Example of a Gentrification: Unintended Consequences of an in Situ Rehabilitation Project in Ankara*
}

\author{
Bir Soylulaştırma Örneği: Ankara'da Yerinde Islah Projesinin \\ Beklenmedik Sonuçları ${ }^{* *}$
}

\section{Reyhan VARLI GÖRK}

Assist. Prof., Department of Political Science and Public Administration, Çankırı Karatekin University, Uluyazı Campus, Çankırı, Turkey rgork@karatekin.edu.tr

\section{Helga RITTERSBERGER TILIÇ}

Professor Dr., Department of Sociology, Middle East Technical University, Ankara, Turkey

helgat@metu.edu.tr

\begin{abstract}
This article is about an early example of gentrification processes in Ankara, the capital of Turkey. A unique form of the gentrification process is examined using a case study of a small inner-city neighborhood on Koza Street through the monitoring of the area between 1998 and 2016, and giving voice to both the gentrifiers and gentrified. Almost ninety percent of the population in the area was displaced despite the inclusionary principles of an in situ Rehabilitation Project which has led to a large scale transformation of the physical space of the street. The study includes four field studies conducted at different time intervals (1998, 2001, 2004, 2009) and a follow-up visit (2016) to the neighborhood, to critically assess the progression of gentrification in Turkey through its phases. Even though gentrification usually refers to the middle class invasion of urban land originally inhabited by the less privileged, our case reveals the effects of successive modes of a gentrification process which starts as an in situ rehabilitation project of a squatter prevention area initiated by a social democratic municipality with the "participation of local groups", and turns into "gentrification by choice" in the successive years in the shadow of "Third Way" values. What is currently happening could be regarded as "gentrification by force" following urban renewal. In our case, however, the line between the two major components of gentrification, i.e., the "gentrifier" and the "gentrified", seems to have become ambiguous, which calls for a further analysis of Turkey's unique political and spatial dynamics.
\end{abstract}

Keywords: Squatter housing, Urban (local) government policy, Third Way urbanism, Urban renewal, Gentrification, Ankara

\section{Öz}

Bu makale, Türkiye'nin başkenti Ankara'da gerçekleşen mütenalaştırma/soylulaştırma süreçlerinin en erken örneklerinden biri üzerinedir. Kent merkezinde Koza Sokak’ta bulunan gecekondu mahallesinin görece küçük sayılabilecek olan bir bölümünün 19982016 yılları arasında gözlenmesi ve aynı zamanda hem mahalleye yeni gelen soylulaştırıcılardan hem de yerinden edilen gecekondu sakinlerinden toplanan verilerin değerlendirilmesi ile özgün bir mütenalaştırma [soylulaştırma] süreci değerlendirilmiştir. İlkesel olarak mahalle sakinlerini proje sürecine dâhil eden bir Yerinde Islah Projesi olmasına rağmen, tüm sokak boyunca ve mahalle genelinde büyük

* Preliminary findings of this study were presented to the $26^{\text {th }}$ World Urbanization Day Colloquium, 6-8 November 2002, Ankara; and to the $22^{\text {nd }}$ World Congress of Architecture UIA, 3-7 July 2005, İstanbul.

** Bu çalışmanın ilk bulguları Ankara'da 6-8 Kasım 2002'de 26. Dünya Şehirleşme Günü Kolokyumunda ve İstanbul'da 3-7 Temmuz 2005'te 22. Dünya Mimarlık Kongresinde (UIA) sunulmuştur. 
ölçekte gerçekleşen mekânsal dönüşüm sonucunda proje öncesi nüfusun yüzde doksanı yerinden edilmiştir. Projenin birinci etabının uygulandığ 47 gecekondu hak sahibinden yerinden edilmiş on dokuz aileden toplanan verileri de kapsayan farklı zamanlarda (1998, 2001, 2004, 2009) yapılmış alan araştırmalarını ve takip ziyaretini (2016) kapsayan bu çalışma, Türkiye'de gerçekleşen 'soylulaştırma' süreçlerinin değişen aşamalarını eleştirel bir yaklaşımla değerlendirmektedir. Soylulaştırma kavramı genellikle, öncesinde imtiyazsız sınıfların yerleşik oldukları kentsel arazilerin orta sınıfların akınına maruz kalması sonucu yerinden edilmesi anlamına gelmektedir. Ancak, Türkiye'deki soylulaştırma sürecinin ilk örnekleri, bu örnekte olduğu gibi sosyal demokrat belediyelerin eşitlikçi, kapsayıcı, ilerlemeci değerleri ile yerinde ıslahı amaçlayarak başlamış; yerel sakinlerin planlama sürecine katılımını özendirmiş; projenin gerçekleşmesi yönünde kaynak yaratma aşamasında özel sektörle işbirliğini “Üçüncü Yol” kentleşmeye dümen kırmış; ve sonunda yerel sakinlerin "tercihen yerinden edilmeleri” aşamalarını izlemiştir. Bugünün kentsel dönüşüm projelerinin sonunda gerçekleşen yerel sakinleri yer değiștirmeye zorlayan süreçler ise “zorunlu yerinden edilme’ olarak adlandırılabilir. Ancak, bizim örneğimizde görüldüğü gibi, mütenalaştırma/soylulaştırma sürecinin bileşenleri olan 'yerinden eden’ ve 'yerinden edilen’ kavramlarının bulanıklaşması Türkiye’ye özgü mekânsal ve siyasal dinamiklerin ayrıca değerlendirilmesi zorunluluğunu gerektirmektedir.

Anahtar sözcükler: Gecekondu, Kentsel (yerel) yönetim politikası, Üçüncü Yol kentleşmecilik, Kentsel yenileme, Soylulaştırma/ mütenalaştırma, Ankara

\section{Introduction}

This article explores one of the first examples of "Third Way Urbanism" in Turkey in an in situ rehabilitation project, which was implemented in the mid of the 1990s, and in turn gave way to a gentrification process. For this purpose, a Third Way Urban Project called From Squatter Housing to Modern Residences Rehabilitation Project (Gecekondudan Çağdaş Konutlara Yerinde Islah Projesi, hereafter abbreviated as GEÇAK RP) in Ankara was targeted for an in-depth analysis. The first phase of this project, also known as GEÇAK RP-1, was initially implemented to affect 47 squatter families living in Koza Street, the upper part of the Kirkkonaklar Gecekondu Region. This initial phase, which began in 1994, was small in size, and thereafter paved the way for the GEÇAK RP-2 in 1998, and others along Koza Street and in the whole neighborhood since that time.

The aim of the article is to review the historic trajectory of gentrification in a small neighborhood in Ankara to critically explore the social and cultural experiences of both the displaced squatter owners and the newcomers. A second goal is to highlight the strategic role of the housing cooperative established by squatter owners themselves as the leading agency in the Rehabilitation Project for Squatter Prevention Areas, their participation in the project as the major initiators of the gentrification process, and the role of the municipality as an intermediary agency between the squatters and the construction company. Finally, during the presentation of the empirical findings, as the struggle for a house, the path from self-help squatter construction towards gentrification is examined in terms of Third Way urban policies.

In order to achieve the goals mentioned above, our case study utilizes a theoretical framework using both a production-side and a consumption-side argument of gentrification. This is because our case represents a hybrid form bringing together the top-down Rehabilitation Project of the municipal government and the bottom-up public support of the squatter owners. While both theories have relevance for the GEÇAK RP-1 case in Koza Street, no single theory is able to explain the whole process. In an empirical study using the example of the sale of statesubsidised houses in South Africa, Lemansky (2014, p. 2955) introduces the concept of "hybrid gentrification", which refers to the fact that occupiers may not only be in a disadvantaged position but may receive also some benefits during the gentrification process.

Early debates on gentrification focus largely on the causes of gentrification. However, gentrification does not necessarily follow a singular path and may emerge when three conditions are present: "the existence of a potential pool of gentrifiers [agents/actors], a supply of inner city housing [supply], and a cultural preference for urban living [demand]" (Hamnett, 1991 as quoted in Gentrification, displacement, 2015, p. 12). Thus, the gentrification process does not only depend on middle classes demanding residential property in the inner city but on various actors like developers, real estate agents, landlords, and (local or central) state policies which may seek to renovate residential or sometimes commercial 
property (generally in the inner city) to increase its market value. The distinctive feature of our case study is that the displaced (gentrified) squatter owners of inner city housing were also among the (gentrifier) various actors demanding for what the other agents were seeking. In a similar way, looking at the demand side of gentrification, Redfern (2003) has expressed the belief that the motivations of gentrifiers, suburbanites and displacees are the same, i.e., a concern for defining and preserving identity. For him what distinguishes the motivations of these various actors are the means at the disposal of each groups. In our case study, the displacees are only concerned with the preservation of their squatter ownership rights and not "with the maintenance of their identity, but do not have access to the same amount of resources as the gentrifiers" (Redfern, 2003, p. 2351).

Since the first use of the term "gentrification" (Glass, 1964) in the social sciences literature, the definition of the term has centered around spatial and social practices that result in the "transformation of a working class or vacant area of the central city into middle class residential or commercial use" (The gentrification reader, 2008, p. xv). It is not spatial upgrading but class dynamics that define the essence of gentrification (Slater, Curran, and Lees, 2004). In general, urban studies concerned with gentrification focus on the problem of displacement (Atkinson, 1998; Atkinson, 2000; Butler, 2007; Hamnett, 1984; Hamnett, 2003; Slater, 2009; Wyly, Newman, Schafran and Lee, 2010). In most cases, after the invasion of working-class neighborhoods by middle-class or higher-income groups, the replacement or displacement of most of the original occupants occurs (Hamnett, 1984; Slater, 2004, p. 4).

However, for Wyly (2015), gentrification does not necessarily displace the original inhabitants. As Atkinson (2000) notes, measuring displacement is like measuring the invisible. Most social surveys are administered at the places of residence where the displaced households used to live but not at the places they moved to. He stresses that to follow the displacees is a very difficult endeavor. As observed in our case study, after the demolition of the squatter housing that gave way to modern apartment buildings within the scope of the rehabilitation project, a small number of the squatter owners chose to live in the project area, and almost $90 \%$ moved to other districts for various reasons displayed in the findings. This could be described as "gentrification". However, unlike" common" gentrification research, this study gives voice to both the gentrifiers and those being affected and indeed displaced by gentrification, and monitors the area between 1998 and 2016. In this sense, similar to Huse's (2014); (see also Lees, 2015) study, our case shifts its lens from a wide angle city or neighborhood scale down to the scale of a particular street-Koza Street in Ankara- and explores urban change through the witness accounts of the researchers and the narratives told by those experiencing gentrification - both the gentrifiers and the gentrified - during a time-span of 18 years.

The study is organized as follows: First we introduce our topic and briefly define the concept of "gentrification". Then we discuss theoretical perspectives on the gentrification process referring to two dimensions (supply and demand) and the link between gentrification and Third Way Urbanism. After presenting the empirical findings, we finish with some concluding remarks.

\section{Literature Review}

\section{Supply versus Demand or Both}

The earliest analyses in the gentrification literature naturally led to a considerable tension between those emphasizing the 'economics of the process' in the production of urban space (the production-side argument) (Smith, 1979, and 1987; Clark, 1988, and 1991; Hammel, 1999a, and 1999b; Freeman, 2006) and those underlining the 'characteristics of the gentrifiers' and their consumption patterns within the broader sphere of urban culture in a 'post-industrial' society (consumption-side argument) (Zukin, 1982, 1987, and 2009; Ley, 1994, and 1996, and 2003; Buttler, 1997; Hamnett, 2003). From the productionfocused viewpoint, Smith (1987, p. 165) claimed that the rent-gap is "the necessary centerpiece to any theory of gentrification", because when the gap is wide enough, land developers, landlords and 'occupier developers' will realize the potential profits to be made by reinvesting in abandoned inner-city properties and preparing them for new inhabitants (Gentrification, displacement, 2015, pp. 12-23). Scholars concerned mainly with the consumption side of the problem, however, place greater importance on the characteristics of gentrifiers and explain gentrification as flows of people rather than of capital (see Gentrification, displacement, 2015, pp. 13-17). Among them, a group of scholars (Caulfield, 1994; Ley 1994, and 1996; Zukin, 1982) focuses on the aesthetic and lifestyle preferences of gentrifiers, who desire a gritty, authentical urban experience or who see themselves as agents preserving the 
nostalgic, authentic character of a place (Brown-Saracino, 2009). Another group deals with neoclassical economics and links land values to housing location choice connected to shifts in the labor market (Hamnett, 2003). Some studies on in-movers have primarily focused on inter-racial/ ethnic gentrification in the American context (Freeman, 2006; Pattilo, 2008).

It is important to emphasize that gentrification processes are not only the outcomes of direct structural forces but also of the engagement of agents themselves: their individual or collective motivations such as profit and status. From the supply perspective, the vast majority of gentrification literature has focused on private actors and capital. However, the public sector also plays an important role in neighborhood transformation. Whether at the central or local level, governments play a role in the neighborhood improvement through investments in physical infrastructure such as roads, highways, rail transit, parks, schools, and sometimes neighborhood based organizations (Gentrification, displacement, 2015, p. 17).

Referring to Smith (2002), Güzey (2006) also acknowledges a systematic partnership of public planning agencies with public and private capital in gentrification processes and underlines the importance of the local government. According to Smith (2002), since its first occurrence in the 1950s and since Ruth Glass coined the word in 1964, gentrification has no longer indicated a local anomaly but a global strategy for urban regeneration. Because the term 'gentrification' has some negative connotations related to class-based displacement and sometimes homelessness, it has become a "dirty word" for developers, politicians and financiers in the European context (Smith, 2002). Nevertheless, "displacement is gentrification itself, it is the natural outcome of any renewal effort given the name rehabilitation, redevelopment or regeneration" (Güzey, 2006, p.4). As observed in Nigeria (Ezema, Opoko, and Oluwatayo, 2016), Hungary (Jelinek, 2011) and many other places in the world, especially in countries struggling to develop, gentrification still has been part of governmentinitiated infrastructural development measures. However, as Davidson (2008) argues, in developed countries like England, state-led gentrification has been promoted by the state itself as a positive process for providing an opportunity to manage the unjust aspects of gentrification, so that the inhabitants of former neighborhoods may not be displaced but mixed with the newcomers.
According to Grier and Grier (1978, p. 2 as quoted in Gentrification, displacement, 2015, p. 25), demolitions that make way for new housing and publicly aided rehabilitation projects are two major causes of displacement in urban neighborhoods. In the authors' understanding, “[d] isplacement occurs when any household is forced to move from its residence by conditions which affect the dwelling or immediate surroundings, and which:

i. are beyond the household's reasonable ability to control or prevent;

ii. occur despite the household's having met all previouslyimposed conditions of occupancy; and

iii. make continued occupancy by that household impossible, hazardous or unaffordable." (Grier and Grier, 1978, p. 8)

Although they use the term "forced" in their definition of displacement, Grier and Grier do not equate "forced" with involuntary. For them, the fact is that many who are displaced are subject to a variety of actions or inactions that may or may not be subtle. Therefore, they conclude:

"For most residents to move under such conditions is about as 'voluntary' as is swerving one's car to avoid an accident. By the time the landlord issues notices of eviction, or the code inspector posts the structure as uninhabitable, few occupants may be left. Therefore, we cannot define displacement simply in terms of legal or administrative actions - or even draw a clear-cut line between 'voluntary' and 'involuntary' movement." (Grier and Grier, 1978, p. 3)

For Newman and Owen $(1982,137)$ distinction between voluntary and involuntary is "untrue" because of its economic reductionist explanations, for "low-income households who experience extremely large rent increases may technically 'choose' to move, but the likelihood that they had any real alternative is very small." In an effort to categorize the causes of displacement, Grier and Grier distinguish between disinvestment displacement, reinvestment displacement and displacement caused by enhanced housing market competition. They do this despite the obvious inter-connections between these three kinds of displacement. Disinvestment-related displacement mainly concerns the conditions under which the value of a property does not justify investing in its maintenance, thereby resulting in decay and abandonment. Reinvestment related displacement refers to the case where investments in a neighborhood results in increased 
rent to a point where it is profitable to sell or raise the rent and tenants are forced to leave. Peter Marcuse (1986)'s analysis of displacement in New York City introduces the concept of "exclusionary displacement" by modifying Grier and Grier's definition above. For him, “exclusionary displacement from gentrification occurs when any household is not permitted to move into a dwelling, by a change in conditions, which affect that dwelling or its immediate surroundings, and which "differs significantly and in a spatially concentrated fashion from changes in the housing market as a whole.”

From a historical viewpoint, Hackworth (2002; see also Hackworth and Smith, 2001), examines gentrification in three periods: a first wave of state-supported, sporadic gentrification in larger cities; a second wave in which localized gentrification became integrated into global and national scale processes, as the state retreated to a laissezfaire position; and a third wave that followed the recession of the early 1990s.

In Turkish cities, the gentrification process has followed its own path and occurred in various patterns (İstanbul'da Soylulaştırma: Eski Kentin Yeni Sahipleri, 2006). For instance, the physical and socio-cultural transformations in Cihangir and Kuzguncuk, two historic inner-city districts in Istanbul, are similar to the Western examples (Uzun, 2003, p. 365). In both cases, there was no government intervention except for legislation regarding the conservation of historical heritage. A significant amount of gentrification, however, generally took place in inner cities, in areas mostly occupied by squatters; and the overall transformation was carried out by the government through urban renewal projects designed to be executed by private contractors in cooperation with municipalities. The Dikmen Valley Project in Ankara can be regarded as a good example: gentrification took place right after the implementation of the Dikmen Project with a partial improvement plan. The first stage of the project was implemented with the participation of the neighborhood during the municipal government term between 1989 and 1993, and was finalized in 1994. However, today, toward the fourth and the fifth stages, this project does not have any social or environmental concerns and largely neglects citizen participation. We use the term 'gentrification' with certain reservations for what was called "in situ Rehabilitation Projects for Squatter Preventive Areas" led by local social democratic municipal governments in the first half of the 1990's aiming to improve the physical space without excluding the former neighborhood residents from the planning process, including them by giving permission to dwell in the improved new houses. However, currently these are led by the central government itself and promoted as Urban Renewal Projects strongly based on some exclusionary principles barring all households in the former neighborhood from dwelling in situ in the new upgraded flats.

The academic literature points to four fundamental changes in the way gentrification works. First of all, corporate developers are now more commonly the initial gentrifiers. Secondly, the state, at various levels, is fueling the process more directly than it did in the past. Thirdly, anti-gentrification social movements have been marginalized within the urban political sphere. Finally, the land economics of inner-city investment has changed in ways that accelerate certain types of neighborhood change (Hackworth, 2002 as quoted in Niedt, 2006). For Wyly (2015, p. 2532) the contemporary evolution of gentrification can be analyzed as a recombinant blend of old and new, and can be defined as the means of class transformation of urban space which are accelerated through intensified competition in work, education and housing.

Smith (1979) and Wharton (2008) see individual newcomer gentrifiers as important, but place a greater emphasis on a broader nexus of actors - developers (financial investors), builders, government agencies, real estate agents - that make up the full political economy of capital flows into urban areas. However, agreeing with Wharton, we argue that gentrification reinforces capitalism through economic demands while at the same time displacing a number of urban inhabitants. As observed in our case study, one of the "supply-side" actors is the government at the local level, which, through public subsidy and policy measures, set the conditions for the In Situ Rehabilitation Project for Squatter Preventive Area, but unintentionally catalyzed gentrification processes. Another important actor, claiming the land as its right owner, was the Housing Cooperative established by the squatter owners, i.e. the local inhabitants of the project area, most of whom were displaced.

Gottdiener (1988, p. 190) proposes five categories of users involved in the turnover of land for profit. These categories could be adopted for our case study as follows: 
i. the owners of the undeveloped land ([gentrified] migrant squatters as in our case);

ii. speculators (landlords/ "gecekondu ağası" in the Turkish case);

iii. developers (municipal and governmental agencies);

iv. builders (construction companies or small-scale contractors - "yapsatçılık" in the Turkish case), and

v. the owners of the developed land (gentrifiers).

What makes our analysis of gentrification distinctive is that our research began with the initiation process, which made accessing the displaced population possible. The research proved that the displaced squatters were not forced to leave the area. As the 19 displaced squatter owners reported, following the execution of the GEÇAK $\mathrm{RP}$, the squatters decided to sell their apartment flats gained through the project even before the demolition, so that they engaged in the gentrification process as one of the chief actors. In line with Redfern's (2003) argument, therefore, we see in our case how the squatters can become one of the actors, by supplying inner city housing, thus being displaced, while at the same time demanding certain advantages from the gentrification process. Still more interesting are the supportive residents who linger on the periphery of gentrification narratives (Niedt, 2006, p. 101).

\section{The Link Between Gentrification and \\ Third Way Urbanism}

In the field of urban politics, Keil (2000, p. 259) differentiates three pathways in a landscape of "possible urban worlds". For Keil, these three pathways are 'social progressive', 'neoliberal' and 'Third Way' urbanism. He believes that these three alternatives are potentially overlapping and sometimes interdependent in their discursive structure in the political arena. According to Keil (2000, p. 262) the dynamics of 'social progressive urbanism' have moved into the realm of civil society and unofficial politics. Among the tangible features of the social progressive urban projects are the emergence of what Harvey (1998) calls "living wage and other new labor-movement strategies" that are decidedly local and urban.

Secondly, 'neoliberal urban politics' are characterized by a combination of two kinds of policies: the neoliberal economic agenda of deregulation, deficit cutting and downsizing of urban government, and the application of a series of policing measures for social control (Keil, 1997; 2000, p. 260). Although neoliberal politics entails the liberation of individual entrepreneurial freedoms, it is often combined with the most conservative social policies that are politically possible: they are often anti-immigrant and always anti-marginal (Keil, 2000, p. 260; Harvey, 2006, p. 27). Because of this contradiction in neoliberalism, Harvey thinks that the neo-liberal state is profoundly antidemocratic, even as it frequently seeks to disguise this fact. In the neoliberal view, the "preferred form of governance is that of the 'public-private partnership' in which state and key business interests collaborate closely together to coordinate their activities around the aim of enhancing capital accumulation" (Harvey, 2006, p. 27).

In Keil's (2000, p. 262) understanding, the Third Way Politics is slightly different from the two others discussed above. It is both a product of independent, social-democratic, liberal and moderate environmental urban politics and a contested terrain located in a field of tension between neoliberal and progressive projects. Most prominently, ecological modernization, entrepreneurialism, cultural modernization, and modest feminist politics are its hallmarks. Urban design is often seen as a means to devising social solutions (Lehrer and Milgrom, 1996 as quoted in Keil, 2000, p. 262). The Third Way is not as conservative as neoliberal projects on social issues, and it is ready to accept social difference and integrate it into the vision of social engineering through urban design (Ibid.: 263).

The shift from the functional-structuralist perspective towards one that underlines agency stresses the importance of the actors in the discussion of gentrification, but this runs the risk of under-emphasizing structural forces and assuming the "homogeneity" of the actors, who are the local people or communities. These local communities are also considered the main actors in Third Way Urbanism. Giddens (1998), now nearly synonymous with the Third Way concept, lists the latter's values as; equality, protection of the needy, freedom within autonomy, rights earned through responsibility, democracy based authority, cosmopolitan pluralism and philosophical conservativeness. In The Third Way and its Critics, the Third Way was criticized for various reasons. One important criticism was its undetermined direction, due to its lack of a defined position. Another was about its incapacity to exhibit a leftist view due to its fall into neoliberal traps (Giddens, 2000).

The Third Way approach agrees with the leftist argument that the market mechanism cannot resolve urban issues, 
but also doubts the role the state can play in the creation of more inhabitable cities and communities (Şengül, 2009, p. 275). Third Way Urbanism practices all comprise a shift from state-centered policies towards civil-societyoriented community participation. As in the case of GEÇAK RP, the transfer of authority to regional local administrations means moving towards democratization and pluralism, although community formed civil society remains vague. The optimism inherent in the Third Way is at its peak when talking about communities (Şengül, 2009, pp. 291-292), regarded as the most important agents; still, what "communities" exactly refers to is not clear. Şengül holds that local communities are groups formed through tradition and solidarity and shared consciousness resulting from a long-lasting coexistence. While Şengül sometimes has doubts about Giddens' understanding of "traditional community", Giddens's 'local community" understanding does not differ greatly from the notion of traditional community. In Şengül's view, in contexts where local groups shape community life according to their own values, the Third Way's basic values of equality, justice and freedom will unavoidably become relative. In other words, there exists the risk of local communities being instrumentalized in the legitimization of many problems, especially social inequalities.

\section{Method}

The study reviews the gentrification processes using a panel study (although not systematically conducted), in 1998, 2001, 2004, and 2009 respectively, and a followup visit of the neighborhood in 2016. Four separate field researches were conducted at different times in the same neighborhood. The initial field research in 1998 [including an unstructured in-depth interview with the chairperson of the housing cooperative founded by the squatters] aimed to gather data on the social and cultural background of the inhabitants of the area. It also included an archival survey in the Department of City Planning at the Municipality of Çankaya District (hereafter abbreviated as MCD) in order to collect spatial, judicial, political and economic information about the GEÇAK RP, namely planning documents, reports and photographs as visual data. This research was not focused on the conceptualization of gentrification, but on the rehabilitation project. In November 2001, using snowball sampling, a second research was conducted, interviewing 19 squatter families out of the total 47 families living in the area prior to the first stage of the entire Rehabilitation Project called GEÇAK $\mathrm{RP}-1$; and the phenomenon was not conceptualized as gentrification, the focus was solely on displacement (Varli Görk, 2002). The data gathered in the second research not only revealed the social, cultural, and economic profiles of the former neighborhood but also revealed why their refusal to live in 'those new modern blocks' cannot be explained in purely economic terms.

The third study was exercised in May 2004, and the gentrifiers who began to occupy the area after the GEÇAK RP-1 were included and the developments in the area were re-conceptualized as gentrification, which began to appear as a new concept in the Turkish academic literature (Uzun, 2003; Varlı Görk, 2005; İslam, 2005). Though the research universe of the study was to include all of the 62 newcomer families, this part of the study was conducted with 19 "gentrifiers" who volunteered to answer the questionnaire and share their social and cultural and economic characteristics. The research was supported by an unstructured in-depth interview with one of the squatters who also still resides in the GEÇAK houses and owns a real estate agency in the same area. In May 2009, the project area and the four housing blocks of the first stage of the project were revisited, and another in-depth interview was held with the relatives of the owner of the real estate agency. Finally, in February 2016, a follow-up visit to the area along the Koza Street was made in order to discuss the whole history of gentrification in the neighborhood.

\section{Research Findings}

\section{The Migration to and Squatters in Ankara}

Only a couple of months prior to the official declaration of the Turkish Republic in 1923, Ankara was proclaimed as the new capital at a time when it was in fact a small town of 20,000 residents, with extremely poor urban qualities. Within its first fifty years, Ankara underwent significant urbanization and expanded exponentially in pace with the surrounding social and economic transformation, ultimately triggering a massive influx of people into major cities, including Ankara (Sargın, 2004). Şenyapilı (1981) argues that the city's urbanization took place as part of a nationwide migration process, and identifies four significant periods: 1945-49; the 1950s; the 1960s; and the 1970s. The original formation of squatter housing in Turkey is a by-product of the mid-1940s, which marks the beginning of mechanized agriculture, resulting in a release of a massive labor force into the relatively developed urban 
environments (Peker, 1996, p. 8; Erman, 2001, p. 985). As the rural market continuously repelled the surplus labor and the 1950-60s became a historically significant breaking point, migration to urban areas reached a peak (Şenyapill, 2004, p. 7). Similarly, Şengül (2003, pp. 158159) calls the post-war period between 1950 and 1980, "the urbanization of labor power." As a matter of fact, Ankara was always a center of attraction for migrants because of its restructuring programs, with a disproportionate vacuum of employment in the public sector as civil servants, workers and officials, and in a limited number of factories. And yet, workers in various sectors were in need of cheap housing, so they built their own homes on public land with what limited resources they could find. The so-called 'gecekondu'; i.e., squatter housing, which lacked technical infrastructure of any kind, was originally constructed in a night ('gecekondu' literally means "built overnight" in Turkish), and expanded over time through the addition of other rooms.

In the history of developing countries, an important policy of socio-spatial segregation has been the demolition of undesirable housing stocks. Indeed, the destruction of low-income housing has never been effective in helping the displaced population (Gilbert and Gugler, 1989, p. 110). In fact, demolition without replacement intensifies overcrowding and increases shelter costs (Abrams, 1964, p. 126). 'The Global Report on Human Settlements' (Zuk at all., 1996, p. 32) highlights neo-liberal policies during the 1980s, where not only central governments, but also local governments and even regional municipal authorities, viewed their role as being responsible for solving housing related and social problems in general. For the poor, the struggle for housing is most often a struggle for land but governmental land policies do not always act for the public good (Satterthwaite, 2009, p. 301). This is so, de Soto claims, because the poor in developing countries already own an incredible amount of land, houses, and businesses; they own capital, but of a special kind: "dead capital," capital that is not officially recognized (Soto, 2001).

Within the modernist paradigm of urban planning, there have been successions of competing theories over the past fifty years. Each new theory (given below in a chronological order) contains subtle epistemological breaks with the Enlightenment tradition in which modernist planning has been embedded: a. the rational comprehensive model;

b. the advocacy planning model;

c. the radical political economy model;

d. the equity planning model;

e. the social learning and communicative action models;

f. the radical planning model (Sandercock, 2000, pp. 423432).

Since the early 1980s the 'transformative power' of planning has been challenged by the model of pluralistic approaches in urban policy. A 'bottom-up' view of how policies were made is now contrasted with the 'top-down' formal exercises in policy making and planning.

Attempting a periodization of the Turkish urban experience in Turkey, Şengül (2003) contributes to the discussion with a long-term perspective for urban studies from a political-economic viewpoint and argues that there can be identified three distinct periods and also three layers of urbanization: i. Urbanization of the state: 1923-50; ii. Urbanization of labor power: 1950-80; iii. Urbanization of capital: 1980-onwards.

In Şengül's (2003; p. 156) view, the first period of urbanization, led by the state during the nation-state formation process, created a layer that interacted with the layer of socio-spatial relations and structures inherited from the Ottoman period. During this term, a nation-wide rational comprehensive plan was exercised to establish a 'modern' nation state and the first comprehensive municipal law was introduced to allow for the establishment of municipal administrations in those localities with populations over 2.000 in 1930 (Şengül, 2003, p. 157).

Şengül (2003, pp. 158-159) calls the postwar period between 1950-1980 'urbanization of labor power', as mentioned before, because of the rapid migration of surplus labor due to the modernization of the agricultural sector in the rural areas and, accordingly, the urbanization of the influx of peasants forming large labor pools in the cities. Between 1950 and 1960, squatting was illegal and considered as dilapidated housing. Measures were taken to stop or to redirect migrant flows. The problem was seen as temporary. The multi-party system of the period was exercised under political patronage. The central government intervened through Law 775 in 1966 (Gecekondu Kanunu, 1966, 30 Temmuz), legalizing and classifying existing stock of housing and prohibiting new stock. Meanwhile, political patronage expanded 
(Gecekondu Kanunu, 1966, 30 Temmuz; see also Keleş, 1987). According to Law 775 (Gecekondu Kanunu, 1966, 30 Temmuz), the gecekondu regions were classified as clearance, renewal and preventive regions. Between 1970 and 1980, populist subsidies were made to rural areas; credit flows and subsidies for agricultural products slowed the rate of migration. Gecekondus were legalized in the process of voting campaigns during the successive local elections. During the 1970s, political radicalization and increasing poverty were experienced in gecekondu neighborhoods. After 1980, the problem was now poverty; rent allocation was provided through Law 2981. The commercialization of squatter areas took place and an important transformation was now in place (Şenyapilı, 2004).

Finally, the post-1980 period witnessed the emergence of another layer characterized by the 'urbanization of capital' which had been an ongoing process throughout the preceding rounds of urbanization, now becoming an overwhelming characteristic of the constitution of urban space (Şengül, 2003, p. 155). To this end various laws were enacted during the period following the military intervention in September 1980 and also after the restoration of democracy in 1983, which strengthened the financial hand of the municipalities. During this period, municipalities became one of the important actors in the process of improving the infrastructure of cities so that the planning model of this period can be defined as social learning and communicative planning.

In accordance with and pursuant to the Law No. 2981 (promulgated in 1984) on the remission of construction set forth by the central government, "all squatter houses constructed up to this date have been legalized" on November 11, 1985 (GEÇAK Project Report, 1995; see also (Gecekondu Kanunu, 1966, 30 Temmuz). As a result of recurring populist policies in Turkey, individuals owned almost five percent of the public land in the project area. In the midst of the 1980s, squatter housing areas in the prestigious regions of Ankara were regarded as 'recyclable green areas' for ecological purposes. Türker Devecigil (2009) defines the period 1984-1989 as "recovery of natural areas under invasion." The intention was to confiscate the lands and turn them into green spaces. Between 1984 and 1989, the above-mentioned Law No. 2981 provided the squatters with the right to possess a share of land in the nearest place to the local rehabilitation plan. According to supplementary laws, the demolition of gecekondus and the displacement of gecekondu owners would not be possible and their rights should be protected in the Squatter Preventive Area(s). ${ }^{1}$

The MCD claimed in their report that the laws and regulations in the 1990s would not solve the problem; as a result, the administration began to seek a 'model' and consequently designed the GEÇAK RP. The Obiter Dictum No. 15270 set forth by the Ministry of Public Works and Settlement in July 251993 permitted the execution of the GEÇAK RP (Değișen Çankaya GEÇAK Leaflet, 1996, p.3). After the implementation of the GEÇAK RP, squatters were supposed to move from a dispersedly located squatter house into a flat in a high-rise building located on the new construction plot in the same location. Thus, the squatter housing areas would be transformed into green areas.

\section{Neighborhood Prior to the Project}

Though the squatter conditions in Ankara tended to have common characteristics, there were internal differences in squatter populations and settlements according to place of origin, religious affiliation, and so on (Ayata, 1989; Güneş Ayata, 1986; Gökçe, Acar, Ayata, Kasapoğlu, Özer, and Uygun, 1993; Erder, 1996, and 1997; Rittersberger T1lıç, 1997; Erman, 1998a and 1998b). The Kırkkonaklar Gecekondu Region including the GEÇAK RP-1 area had a population of 15.000 in the 1990s. There are extensive discussions on the representations and self-representations of gecekondu dwellers in the existing literature, but these remain out of the scope of this study. ${ }^{2}$ According to the Report on GEÇAK (Çankaya Belediyesi İmar Müdürlügüu, 1995), the wider region including the project area covered a total space of 9.33 hectares on which were from the villages of Bayburt, a province in the eastern part of the Black Sea Region, who arrived in the 1950s; however, migration

1 Erman (2001, p. 994) mentions 'the undeserving rich'. The emergence of a new group of gecekondu residents who became wealthy in a short period of time led to complaints such as "Once upon a time they built their gecekondus overnight, and now they are becoming millionaires in a day".

2 In order to reveal the occupiers' various representations Erman (2001, p. 2004) reviews gecekondu studies ranging from the earliest to the most recent ones. She suggests that the representation of gecekondu dwellers varies by time period; namely, the "rural Other" in the 1950s and 1960s; the "exploited/disadvantaged Other" in the 1970s; the "diversified Others in terms of ethnicity, religious sect and gender," and the "undeserving rich Other" versus the "urban poor Other" in the 1980s and 1990s; and finally the "threatening Other/varoşlu" vs. the "gecekondu dwellers as agents" in the late 1990s and 2000s. 
intensified in the 1960s. The original population mostly comprised villagers $(84.4 \%)$, and $27 \%$ of the population felt more like urbanites, while $54.9 \%$ defined themselves as villagers (Ulufer and Çırak, 1997).

Displacement and abandonment may result when the gentrification process begins (Smith, Duncan and Reid, 1988). However, less is known about those who are displaced for the simple methodological reason that it is harder to investigate those who have dispersed socially and spatially than those who have come together (Legates and Hartman, 1986). Unlike most gentrification researches, this study was based on questionnaire interviews with displaced squatters subjected to the first stage of the GEÇAK RP in 2001, obtained by using the snowball technique. The snowball sampling of the displaced population began with three respondents working as taxi-drivers in the project area. The interviewees all reported that they had lived in the neighborhood prior to the implementation of the

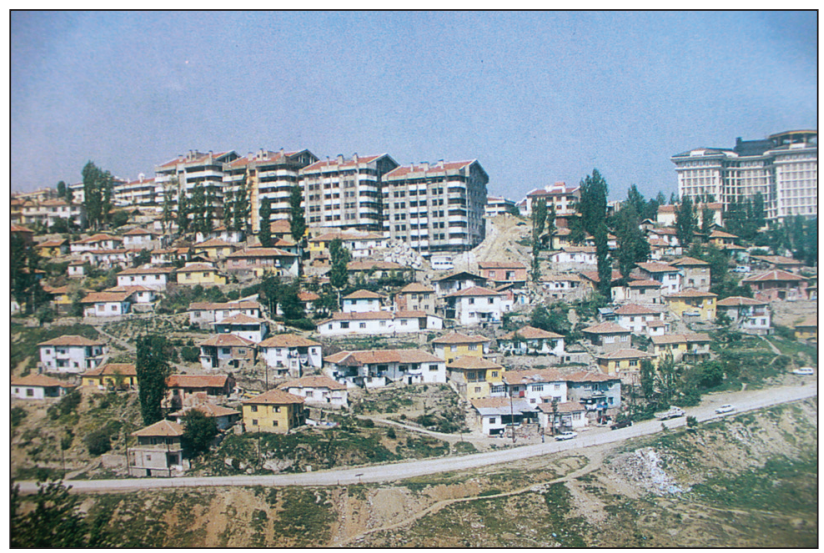

Figure 1. Squatters on the plots reserved for the GEÇAK RP2 (After the implementation of the GEÇAK RP-1).

Source: Değişen Çankaya, GEÇAK RP Leaflet, 1996). project and that they used to work in public institutions, small industrial workshops or the service industry.

Among the 19 squatter families accessed out of the original 47 in the GEÇAK RP-1, the earliest migrant family had moved into a squatter house in the project area in 1954 and the most recent family had arrived in 1967 (Figure 3 ). Though the wider region (Figure 1 and 2) is more heterogeneous in demographic terms, almost $75 \%$ of the displaced first generation migrant families were originally from villages near Ankara, and since their arrival they had resided in the sampling region for over forty years (Figure 4). In addition, $75 \%$ of the displaced families occupied their plots illegally, through the invasion of public lands, buying invaded illegal lands, or through inheritance (Figure 5).

\section{From in situ Rehabilitation of Squatter Preventive Areas to Urban Renewals}

In Turkey, under the name of "in situ Rehabilitation Projects" urban renewals were first seen in Ankara in the late 1980s during the social democratic mayor Murat Karayalçın's administration. A glance at these projects in general reveals a shift from holistic planning towards small scale, participation-based practices through private initiatives. During this term, medium scale build-and-sell (yap-sat in Turkish) construction companies were seen as partners for the first time in the Dikmen Valley and Portakal Çiçeği Valley redevelopment projects. The goal of these projects was to increase the quality of infrastructure in the gecekondu areas and to create livable areas and healthy urban spaces. In the 1980s, the global scale-planning paradigm shifted from macro-scale rational decisions and comprehensive planning toward various micro-scale projects and mixed ways of decision making. Uzun (2008), classifies the post-1980 urban renewal areas in Ankara into two groups. The first are those like the Dikmen Valley and

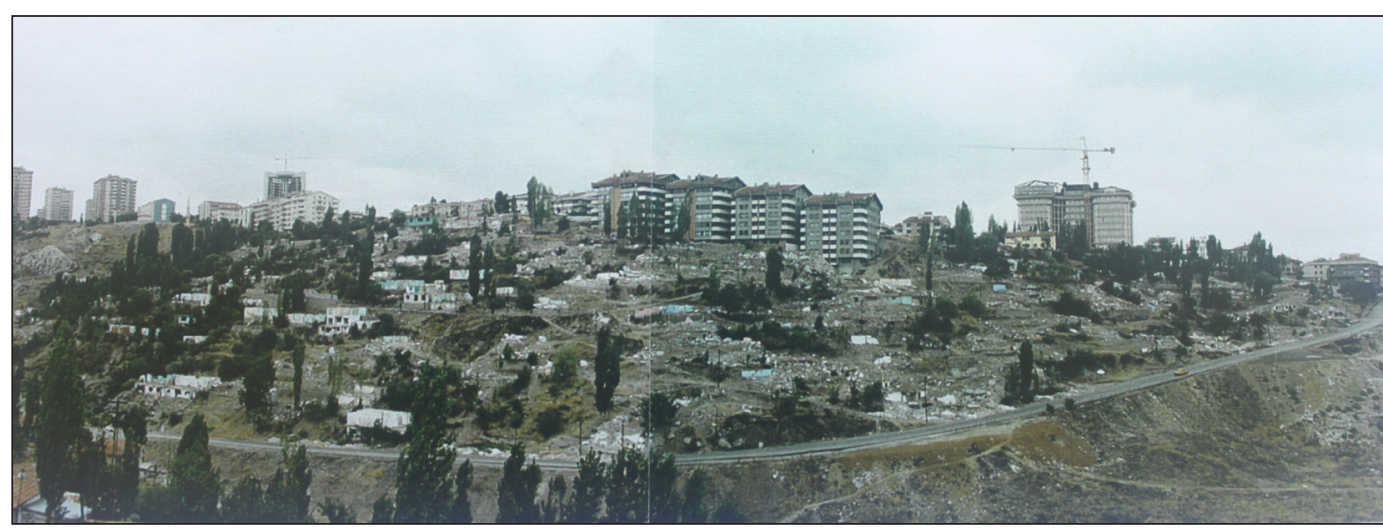

Figure 2.

Demolitions of the Squatters in the area reserved for the GEÇAK RP2 (A view from the opposite side of the Valley).

Source: Bülent Güler, 1996. 


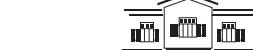

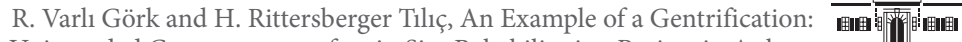

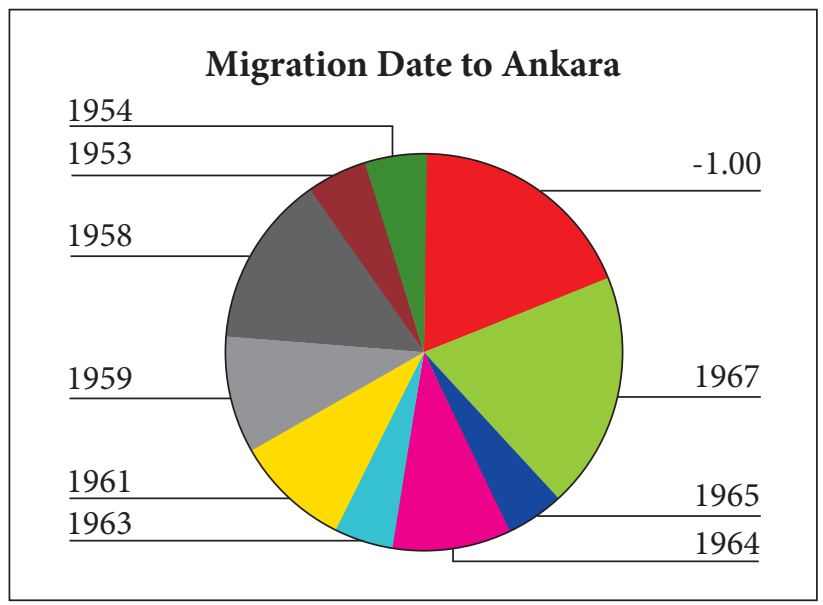

Figure 3. Squatters' migration dates. 2001 field research.

Portakal Cicegi Valley Urban Transformation Projects; and the second are those renewed through residence cooperatives formed by local communities. The main difference of the second type is that for the first time three main groups were defined as participating shareholders for the project's implementation: the municipality; the private sector (the commissioned construction company); and the cooperative established by squatter house owners. During this period, the Ankara Greater City Municipality and MCD approached squatter neighborhoods as "modern housing plots and recreational spaces" and they acted as a guide, encouraging the squatters to unite by forming cooperatives in the "landowners' struggle to become rightful owners" (Türker Devecigil, 2009, p. 204).

Following the victory of a right-wing party in the 1994 local elections, the rehabilitation projects in Ankara began to be regarded as urban renewal projects with high rentier potential. As observed in the Dikmen Valley Project, an urban rehabilitation project might begin with social democratic principals in its first stage, then might adhere to the Third Way values in its second, and then might sharply embody neoliberal policies toward its final stages

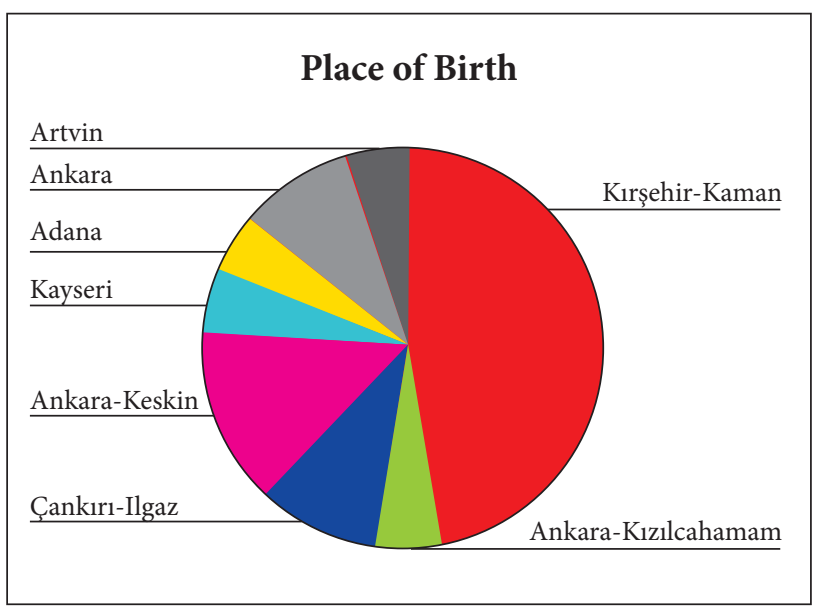

Figure 4. Place of birth of the squatters. 2001 field research.

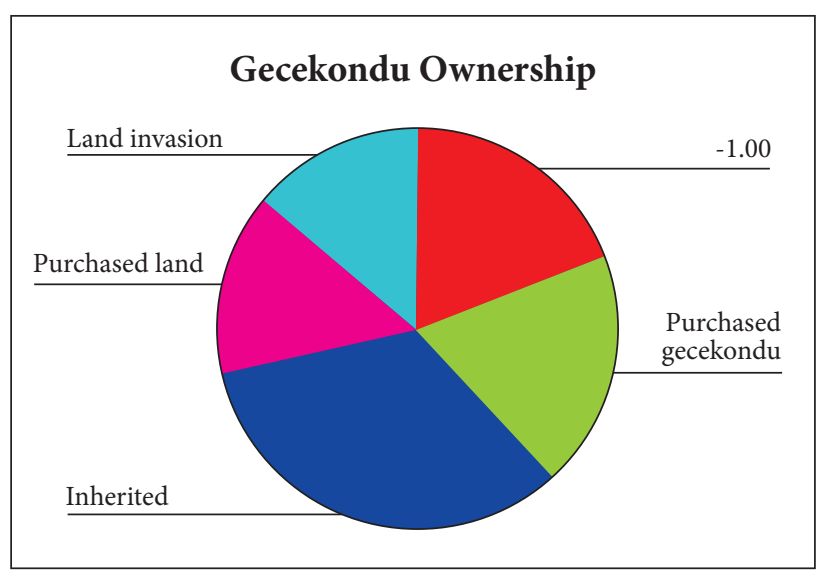

Figure 5. The way of acquiring title deeds of the gecekondus. 2001 field research.

because of the shift in urban policy in accordance with the political party of the mayor. Today, to complete the fourth and fifth stages of the project, the original population of the Dikmen Valley has been forced to leave the area. The new destination for the squatters is houses built by the $\mathrm{TOKI}^{3}$ in Mamak, another municipal district in Ankara.

3 The Housing Development Administration Fund Law was passed in 1981 to resolve the housing problem and increase housing production at national level. In 1984, Housing Development Administration Law came into force. In the same year a new and legal entity, the Housing Development and Public Participation Administration (Toplu Konut İdaresi, TOKI) was established. In 1990 TOKI was transformed into a separate entity. In 2002, TOKI was affiliated with the Ministry of Public Works and Settlement. Then, in 2004 TOKI was linked to the Prime Ministry. As can be read from the official website, since 1984, TOKI has been acting to provide "housing for the low and middle-income groups". It had provided housing loans to approximately 1.2 million housing units by the end of 2004. Among these numbers, housing cooperatives had the biggest share (84\%). In addition to the loans given to cooperatives, municipalities were also supported. The data on the site (2009) refers to 547,625 Housing Units, in 81 Cities, 800 Towns, with 2,389 Construction sites. TOKI moved a long way from "social housing" to an understanding that does not only include "social housing" but also "shopping malls". This can be also read from the slogan: "We Are Building the Cities of the Future for the Future of Turkey"( http://www. toki.gov.tr/). 
Today, many municipal administrations, in particular the Greater City Municipalities and TOKI together, are preparing the implementation of urban renewal projects, ranging from the redevelopment of gecekondu areas to construction of residences and large shopping malls, which attract the attention of real estate investment shareholders and partners of international capital (Ergün and Gül, 2009 , p. 304). Whether for residential or commercial spaces, the projects carried out jointly by the TOKI and the Greater City Municipalities target the consumption of upper middle class income groups. More often than not, the economically disadvantaged inhabiting these spaces are forced to move to the TOKI apartments ${ }^{4}$ built in the outskirts of the city. Thus, the urban poor are not only rendered invisible in their new areas outside the city, but also marginalized.

The GEÇAK RP-1 project was implemented by the MCD toward the end of the 1989-1994 municipal government period, while the mayors of the MCD and the Greater Ankara Municipality were from the Social Democrat People's Party. During this term, squatter areas like the one covering the western side of the Kirkkonaklar Valley including GEÇAK RP1 were defined simply as "urban areas" (Türker Devecigil, 2009, p. 203). In time, the renewal projects were called "urban transformation projects", which prioritized balanced environment and designed as self-financing models. They were monitored by municipalities as the mediating institution between squatters as the rightful owners, and the contractors. Increasing the zoning rights in the project areas would be a way to fund the projects. Within the scope of the GEÇAK RP-1, the MCD 5 first encouraged those residing in the squatter neighborhood where the project would be implemented, to form a housing cooperative, and then gave them the title deed to the project area, which had turned into a cooperative land. ${ }^{6}$

\section{The Geçak Rehabilitation Project}

The MCD submitted the GEÇAK RP to the central government in 1994 and the project was approved without major reservations. As mentioned in the Report on GEÇAK, the model was explained to the participants during instructive and interactive meetings. Meanwhile, the attendants were persuaded to participate in the project via housing cooperatives; and in total, 221 squatter houses were listed in the project area (built before 11 November 1985). The MCD, pursuant to the Law No 5656 set forth by the central government, was obliged to assign a part of its land through sales to the people occupying its land (Keleş, 1987). According to the MCD's Report on GEÇAK, the goal of the project was to achieve local democracy by starting the democratic active participation process in the regions where it was to be implemented. The prerequisite of the project was that citizens are organized in a cooperative. Following the advice of the MCD, the Besa Housing Cooperative was founded by the gecekondu owners that can be referred to as a "local community" in the Third Way construct as an example of solidarity and shared consciousness born of prolonged co-existence.

In the Report on GEÇAK, it is claimed that the problems arising from the varying shares among those entitled in the cooperatives will be resolved, that the perception of unfair annuity gain from city lands will be changed, and that an urban consciousness will be created. However, during the implementation, the unequal size of the gecekondu owners' lands and the unequal distribution of annuities caused problems (Kuzu, 1997). According to Kuzu (1997, p. 191), in terms of planning, the GEÇAK RP is an example of Leverage Planning because of the following features:

It encourages private sector investment; allows for incentives and licenses for construction of housing on public land; envisages that the municipality will provide infrastructure and project facilities; allows the municipality to play an

4 For TOKI apartments see Erman's (2016) book, Mış Gibi Site: Ankara’da Bir TOKI - Gecekondu Dönüşüm Sitesi [As if Site (Building Complex): A TOKI in Ankara-Squatter Settlement Transformation Site], which analyzes neoliberal urban renewals of inner city squatter settlements in Turkey in the case of Karacaören TOKI apartments. See also Aslan and Güzey’s (2015) study "Affordable Housing Provision: A Case Study of TOKI Ankara Kusunlar Low-Income Housing."

5 The Mayor of Çankaya District declared that" there were 38 more cooperatives, waiting to be officially established. [...] By forming formal relations with those of new initiatives in line, at least half of all squatter housing in Çankaya District were about to be transformed into modern housing stocks" ("Gecekondu'ya Yerinde Islah Modeli”, 1994, 13 Şubat).

6 The Besa Housing Cooperative (Figure 7, Figure 8), formed by 47 squatter housing owners under GEÇAK RP-1, purchased the deed for $3960 \mathrm{~m}^{2}$ of the land, which corresponded to 5 parcels of the $7000 \mathrm{~m}^{2}$ land made up of 18 parcels for 1 million Turkish Liras in 1994 ("Gecekondu'ya Yerinde Islah Modeli", 1994, 13 Şubat). The price of the deeds bought by the Besa Housing Cooperative members was paid to the MCD by the contracting firm. Later, the squatter houses covering the 18 parcels of land were torn down, allowing the contracting firm to start the construction. 


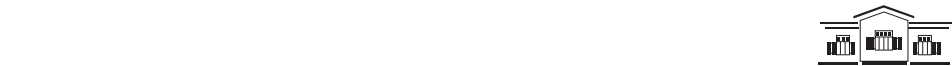

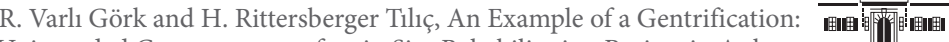

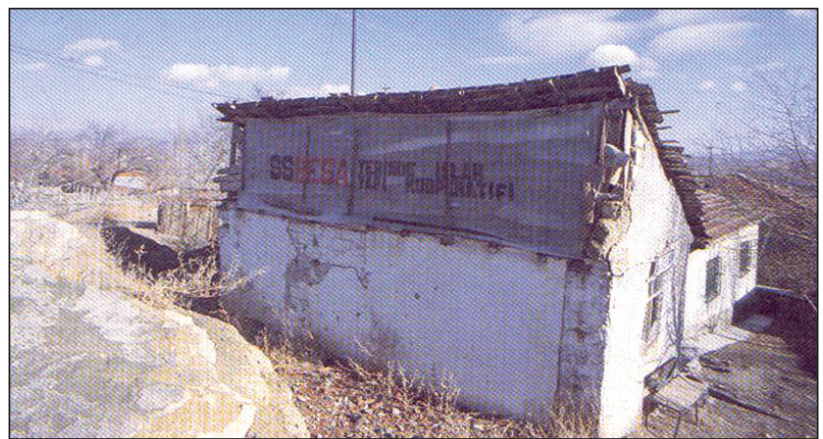

Figure 6. BESA Housing Cooperative Office.

Source: Reyhan Varlı Görk's Collection, early 1990s.

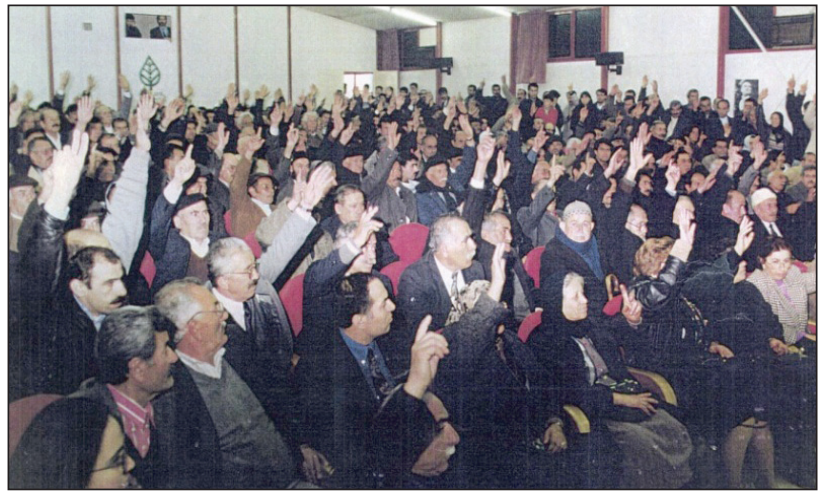

Figure 7. Meeting of the Besa Housing Cooperative Members established by the Squatter Owners.

Source: Bülent Güler, 1994.

active a role in each stage of the project as well as carrying out the determining and controlling tasks; and provides for the municipality to be in close contact with the private sector and squatter owners (Kuzu, 1997, pp. 191-193).

In terms of urban policy, because of the active involvement of the housing cooperative, the GEÇAK RP is reminiscent of Third Way urbanism, with the leading agency of the municipality as the local government encouraging the private sector. The Besa Housing Cooperative not only provided organized participation (Figure 6 and 7), but also became the initiator of the GEÇAK RP. The MCD insisted that the GEÇAK RP was designed to overcome

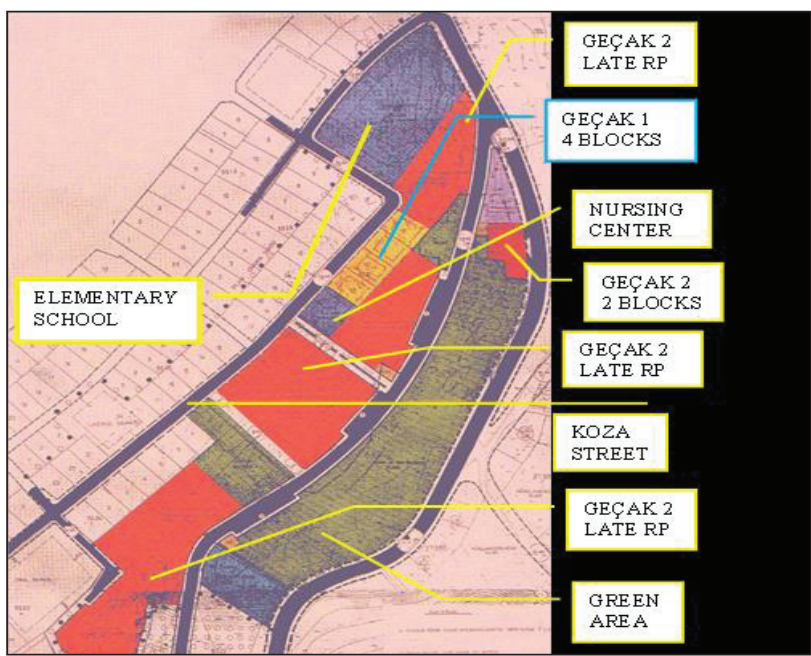

Figure 8. The GEÇAK Rehabilitation Project Development Plan by the MCD.

Source: MCD Archive.

the shortcomings of squatter housing while protecting the rights of the dwellers all at once. Thus, the squatters would be able to live in their familiar social environment even after moving to their new apartment flats. Since the project was to meet the expectations of all participants, Neșet Cayır, the first chairman of The Besa Housing Cooperative, regarded the GEÇAK RP-1 as a 'successful project'?

The first stage of the GEÇAK model ${ }^{8}$ called GEÇAK RP-1 was small in size and the implementation of other stages GEÇAK RP-2 (shown in red) was achieved soon after (Figure 8). The GEÇAK RP-1consisted of four apartment blocks with six floors constructed on the four plots (shown in yellow in Figure 6) reserved for the 47 squatter house right owners. The first two blocks, which consisted of 47 apartments and two janitor flats, were reserved for them. Among them, 41 right owners got the keys of their flats on October 26, 1996 ("Anahtar Teslimi," 1996). The two other blocks given to the construction company in return for the expenses of the project were relatively more luxurious in terms of construction materials, consisting of a total of 19 apartments, with half of them as duplexes. As prescribed

7 See "GEÇAK Projesi çerçevesinde gecekondular davul-zurna eşliğinde yıkıldı", [Within the framework of the GEÇAK Project gecekondus were demolished with joy], http://www.porttakal.com/ahaber-GEÇAK-projesi-cercevesinde-gecekondular-davul-zurna-esliginde-yikildi-66379.html)

8 Four residential islands (shown in yellow, Figure 6) were reserved for the first stage of the GEÇAK Project according to the plan prepared by the City Planning Division of the MCD. The section that was proclaimed as inconvenient for housing was set aside for parks and recreational areas as well as a separate children's playground. The cultural center was also reserved for the residents to meet their recreational needs. The area located to the north of the site, deemed the most suitable place for accommodation, was designed by the City Planning Division of the MCD to serve as a residential and commercial area, kindergarten, school and playground. 
by the MCD, the first aim of the GEÇAK RP-1 was to obtain a well-designed green environment with healthy surroundings, and residents integrated into the city. Its second aim was to provide a healthier environment for the squatters within the same location.

With the GEÇAK RP, the first aim was on-site rehabilitation in the gecekondu prevention region. While the GEÇAK RP could be considered an example of how public property can be turned into private property, it could also be seen as a social project in that gecekondu owners later came into possession of valuable property as a result of the transfer of the ownership to them. The case of the GEÇAK RP illustrates how the local community based solution of the Third Way approach runs the risk of further complicating the participation problem in urban Turkey. As Şengül argues, the Third Way approach leans towards a participation model based on entrepreneurialism at the urban level, and this model has reinforced a participation practice based on a search for demand (Şengül, 2009, p. 300). During the implementation of the project, the values of the local community forming a housing cooperative as one of the shareholders of the project have become confused with the values of the other shareholders. This confusion masks the truth that the gecekondu owners as the gentrified have also been acting as the gentrifiers from the start, since the unequal partnership of the housing cooperative made up of the local community, as a relatively disadvantaged participant, is concealed by Third Way values. The GEÇAK RP aiming to resolve the gecekondu phenomenon in situ ended up unintentionally displacing the former neighborhood. As Redfern (2003, p. 2354) stresses "the creation of an opportunity does not mean the taking up of that opportunity, unless the demand is there." To put it all in simple terms, by transforming the "dead capital" of squatter house right ownership into a vital one, they gained title deeds to the flats in situ but lost their community identity in their former neighborhood.

During the field research conducted in 1998, Mr. Çayır, the chairman of the Besa Housing Cooperative, stated that only eight of the 47 families did not sell their flats, and four of those eight families leased their flats to other people. He believes that the main reason they opted not to live in those apartments was economic. The lowest going rate of any apartment in this area was enough to buy two or more in other parts of Ankara. According to Mr. Çayır, another reason they sold their apartments was the size of the GEÇAK RP1 houses, $80-90 \mathrm{~m}^{2}$ with two bedrooms and one living room. These flats were simply too small for families with more than three children. This was also expressed by Malusardi and Occhipinti (2003), who studied another gecekondu neighborhood in Ankara, stressing that gecekondu families often complain about the lower quality of life, because of the insufficient size of their flats considering their crowded families; and the loss of their tightly knit kinship and community networks.

In November 2001, only eight of the forty-seven families were still in possession of the GEÇAK houses that had replaced their gecekondus. This was partially because social, economic and cultural factors pushed the old squatters out of this area after the project. Most of the displaced 39 families sold their houses and bought two or more apartment flats in other regions where real estate prices were lower. As they stated, they had decided to move away to other districts even before the implementation of the RP, because they saw the GEÇAK RP-1 as a profitable means of replacing their squatter houses. Furthermore, all of the 19 displaced respondents stated that they never intended to live in the GEÇAK houses after the implementation of the project. A few of the displaced families leased out their apartments for more income and continued to live in nearby neighborhoods. Despite their participation and the project's aim of keeping the original population in the project area, most of the squatters had 'chosen' to leave the neighborhood before the 'invasion' of the newcomers.

In May 2004, a research was conducted among the newcomers. Only 19 families living in a total of 66 flats responded to the questionnaire. Eleven newcomer respondents were from the first two blocks, which were sold by the private owners who had formerly been squatter right owners. Eight were from the other two blocks, which were sold by the construction company to the newcomers. In order to see the difference, the results were evaluated separately since the gentrifiers of the first two blocks were much younger than the residents of the two other more luxurious blocks, and mostly single women. In gentrification studies it is generally argued that the gentrified city serves professionals, managers, technicians, and yuppies in their twenties and college professors in their sixties (Marcuse, 1997, p. 704; Butler, 1997, p. 35). The first two blocks primarily reserved for the squatters in the area were "gentrified" by a professional manager, financial consultant, medical doctor and biologist in their late twenties and thirties. The second two, relatively more luxurious blocks reserved for new residents were 
"gentrified" by a diplomat, technical manager in the private sector and a medical professor, all in their fifties and sixties. They described themselves as upper class.

Due to the gentrification process after the implementation of the RP, the 2004 survey reveals that only four of the 47 squatter families were living in the GEÇAK houses. Two households classified themselves as lower-middle class and one as working class. Only one of them identified his family as upper-middle class. One of the informants owned a real estate agency in the project area and was also one of the gecekondu owners in this project. As he said, his father was the squatter landlord [gecekondu ağast] ${ }^{9}$ mainly active in the1960s and 1980s, and he himself had been in the real estate business since the 1980s. According to all displaced respondents, some squatters got multiple shares by introducing "fake" squatters in the project area. After the implementation of the project, they retrieved the title deeds from these fake right owners.

The real estate agency owner's family is one of the four families still living in the GEÇAK apartments. Nevertheless, they are displeased about the new conditions in the area; for instance, according to the interviewee's account in 2004, during the Ramadan Holiday, they wanted to pay a visit to one of their new neighbors to celebrate the holy days, but their new neighbors did not invite them in. His statement below shows how perceptions conflict among "newcomers" and "natives"; it also demonstrates how status and life styles determine perceptions:

We are richer than the neighboring family whom we visited, but they insulted my family, because we used to be squatters. They never even greeted us (in the hallway) afterwards. They think that we are "nouveau riche". In truth, this street belongs to us. We have been living here for more than 40 years. They are the newcomers. We are the natives, and they are the outsiders.

Revisiting the street in May 2009 reveals that the number of squatter families living in the GEÇAK RP-1 apartments increased from four to six. During the field research, one interviewee, the son of the aforementioned real estate agency owner (third generation) in the project area, stated that in 2008, he got his own apartment in one of the first two blocks. He also mentioned that one of the squatters had returned to the GEÇAK RP-1 apartments 13 years after the implementation of the RP. Findings from 2004 suggest that $20 \%$ of the 127 apartments in the four buildings built under the GEÇAK RP-1 were commercial businesses, while this rate reached $60 \%$ in the findings of the 2009 field research (Figure 9-11). Those who bought apartments in the first two buildings with the intention of living there

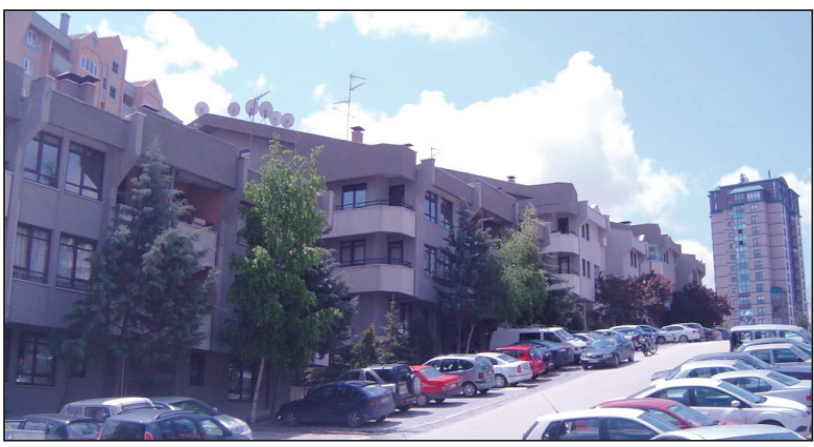

Figure 9. GEÇAK RP-1 Four Blocks, Koza Street.

Source: Reyhan Varlı Görk, 2009.

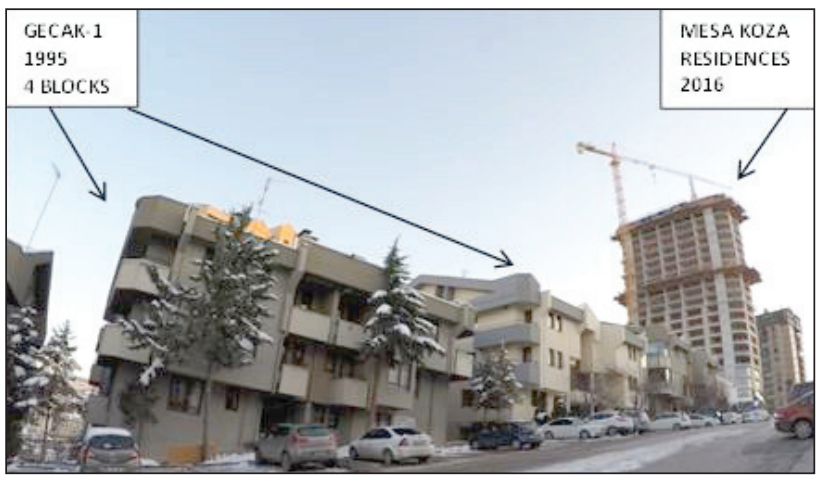

Figure 10. GEÇAK RP-1 and MESA Residence Construction. Source: Reyhan Varlı Görk, 2016.

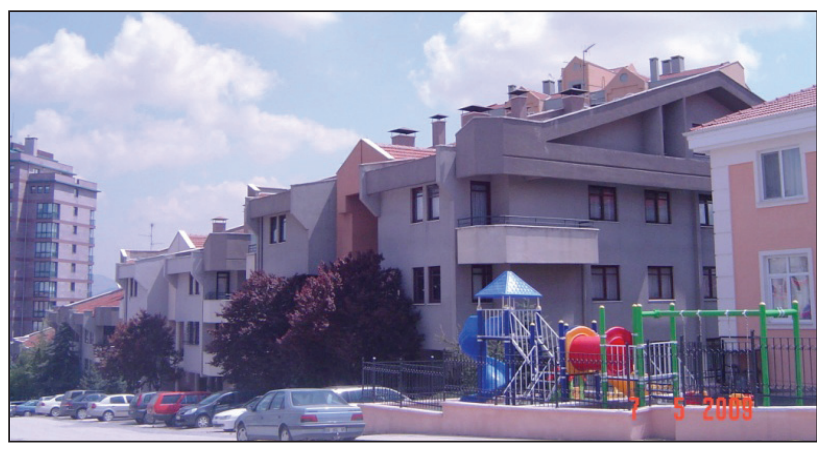

Figure 11. Kindergarden GEÇAK RP-1 and GEÇAK RP-2 on Koza Street.

Source: Reyhan Varlı Görk, 2009.

9 "Gecekondu ağasi" is one of the "five categories of users involved in the turnover of land for profit" in Turkey, as mentioned above. 
are still residents. However, the apartments leased are increasingly becoming commercial businesses (Figure 11). Among the businesses in the first two blocks are realtors, car rental companies and architectural design offices. The overall population living in the other two blocks, which are more luxurious, are not very different from the population mentioned in the 2004 field study; with the exception of one, which now has a commercial function. The 2009 field study shows that the inhabitants of these two apartment blocks consist of retired politicians, diplomats, doctors, businessmen and administrators in their sixties.

Another field visit in February 2016 revealed that not only Koza Street but entire sections of the neighborhood located on the opposite side of Kurkkonaklar Valley and down to Dogukent Boulevard have been undergoing upgrading and increase in real-estate value (Figure 13). High rise prestigious residence towers are lining Koza Street (Figure 10-12). Today, in comparison to these residences, the first

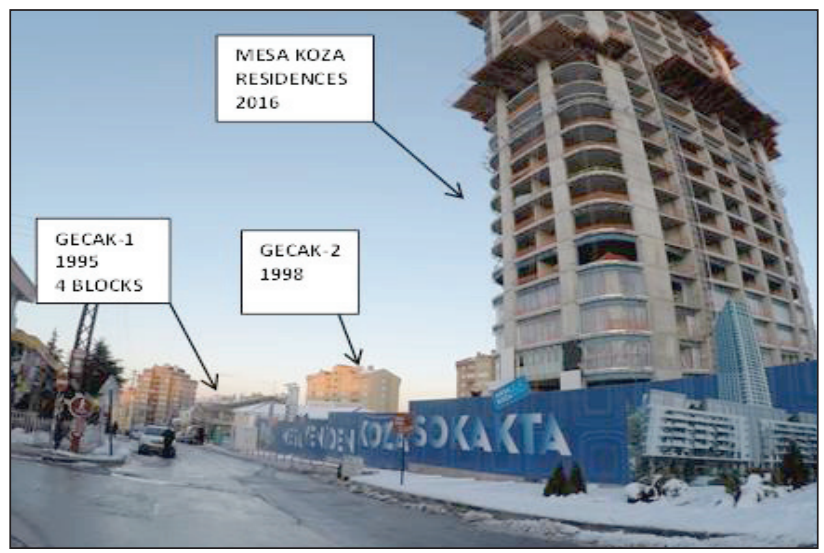

Figure 12. MESA KOZA Residences, GEÇAK 1 and GEÇAK 2 on Koza Street.

Source: Reyhan Varlı Görk, 2016. four blocks of the GEÇAK RP-1 (Figure 9) look relatively modest in appearance. The expansion of the physical upgrading along Koza Street deserves further research to examine the underestimated magnitude of the process and therefore "chains of displacement" should be also considered (Marcuse, 1986).

\section{Conclusion}

Discussions on gentrification focus on factors forcing the urban "poor" out of their neighborhoods, to be invaded by "upper" strata, which Smith refers to as the revenge of the middle classes (Smith, 1996). The gentrification of urban neighborhoods can be regarded as a result of uneven economic processes relying on land speculation. It is interesting to analyze the various actors and alliances taking part in this kind of a process. The main role is usually associated with private enterprises (local or national) and/or local/national governments. This study actually addresses the fact that certain sections of the population living in originally poor but potentially attractive neighborhoods become important agents themselves in the transformation processes. Thus, not only the so-called 'invaders' but the 'dwellers' in the neighborhood as well, might avail themselves of economic advantages. Not all of the individuals living in the neighborhood end up being victims; some actually establish and initiate alliances with economically powerful agents.

The study deals with a population, which originally illegally occupied state-owned land, constructed low standard housing, and settled in these so-called gecekondu neighborhoods. The GEÇAK RP aimed to ameliorate the housing and infrastructural conditions in situ, i.e., without resettling the population living there. The stateled rehabilitation project first provided a legal basis through the provision of title deeds. Owners would then

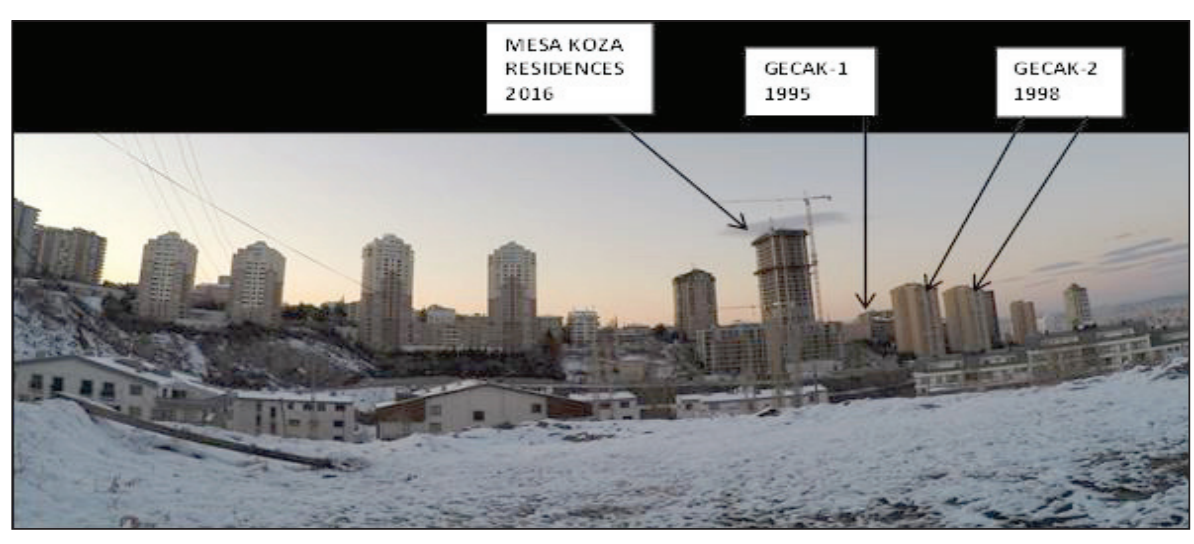

Figure 13. MESA KOZA Residences, GEÇAK 1 and GEÇAK 2 and other high rise residences on the plots planned by the MCD (A view from the opposite side of the valley). Source: Reyhan Varlı Görk, 2016. 
receive a flat in the apartment buildings to be constructed in return for their gecekondus. Following the meetings organized by the MCD, a great majority of the squatters readily agreed and formed an alliance. They actually established a cooperative to support the renewal plans of the municipality. The driving motive was clearly financial gain, taking into consideration that most opted not to move into the newly constructed flats (which also meant higher monthly maintenance fees, etc.) and instead chose to move to other neighborhoods (after selling or leasing out their "new flats").

Despite the initial objective of the GEÇAK RP, only six of the forty-seven families still own their flats today. At first glance, the main reason the majority chose not to live in these flats seems financial, as one flat in this area is easily worth two or more flats in other neighborhoods. Another important reason for them to sell their flats was the inadequate size, only about 80 to $90 \mathrm{~m}^{2}$, with a maximum of two bedrooms and one living room. These flats did not meet the needs of the families. With an average of more than three children, the families were in need of larger flats. The squatters left their gecekondu neighborhood long before the invasion of the "genteel" newcomers. At this point one may argue that there is no "gentrification" occurring in this area since nobody was forced to leave the neighborhood. Rather they were "rewarded" by legal title deeds for their illegal squatter house plots, yet they chose to leave the area. All of the 19 displaced families interviewed stated that they had never intended to live in the GEÇAK flats after the implementation of the project but sell or hire them. From the production side of gentrification, the squattersthe displacees-acknowledged the GEÇAK Project as a profitable 'means of production'. By stating this, the authors do not attempt to reproduce a common discourse blaming gecekondu owners as materialistic, but to underline how Third Way urban projects, easily lose their universal aims and values. As mentioned in the introduction, the demand issues in this unique gentrification case cannot be explained without mentioning the motivations of the displacees. Gentrification occurs due to many reasons, including the ones experienced in this case (Grier and Grier, 1978). As Redfern (2003, p. 2354) stresses "the creation of an opportunity does not mean the taking up of that opportunity, unless the demand is there."

In our case, the housing cooperative established by the squatter owners seemed to be the most effective agent during the planning period of the rehabilitation project.
However, the squatter owners, as agents acting according to their values, did conflict with the universal claims stated by the project, i.e., the project's aim to renew the neighborhoods and keep the population in place.

In our case, from the production side viewpoint of gentrification, there are basically three parties to be considered: firstly the municipality; secondly the construction company; and thirdly the housing cooperative (gecekondu owners). The gecekondu owners were motivated by a social justice discourse of social progressive urbanism policy, which refers to environmental-justice, citizenship struggles, progressive identity, community economic development, etc.; the construction company was naturally motivated by economic profit of neoliberal urbanism policy in which the preferred form of governance is public-private partnership; and the municipality combined these two interests in a Third Way urbanism policy which suggests combining social solidarity with a dynamic economy. The wind of the Third Way in the 1990s, with the support of the local community, shifted the direction of the GEÇAK RP from social solidarity toward dynamic economy. Since the gecekondu owners lost their direction in the Third Way, we claim that the gentrified and gentrifiers blurred on the Third Way.

However, this is not to say that there were no grievances during the course of this process. In fact, during the GEÇAK $\mathrm{RP}$ process, there were several people in disadvantaged positions (mainly tenants or squatter owner families, who had not petitioned to become members of the GEÇAK Housing Cooperative) other than the 47 "lucky" squatter families who gained a flat in the first two blocks of the GEÇAK RP-1. Urban rehabilitation projects in Turkey, also referred to as 'urban renewal', usually displace the residents living on these project sites prior to the implementation of the project. As discussed in the literature section, from a historical point of view, the GEÇAK in situ Rehabilitation Project, led by the social democratic municipal government in 1994, can be regarded as an early example of the "first wave of state-supported, sporadic gentrification in larger cities" in Turkey. It was initiated in a social democratic local government period, motivated by Third Way values of "participation of the local groups" and the neoliberal values of the construction company, but ultimately turned into "gentrification by choice". However, nowadays, while neo-liberal municipalities in Turkey still encourage "participation of local groups" in gecekondu areas, they are actually asking these groups to leave these areas, by 
sending them to TOKI houses in different districts, i.e., "gentrification by force". Here, we do argue that new housing policies are harsher and more disadvantageous but the case analyzed in this article is to be considered as important because it addresses at the role played by local residents and developers in the gentrification process. Thus, gentrification should be understood as a complex and heterogeneous process.

\section{References}

Abrams, C. (1964). Man's struggle for shelter in an urbanizing world. Massachusetts: MIT Press.

Anahtar Teslimi [news]. (1996, 16 Ekim). Cumhuriyet. Accessed on Jan. 13, 2012 at http://www.gundemturkiye.org/detail. php?\&id $=26275$

Aslan, S. and Güzey, Ö. (2015). Karşlanabilir konut sunumu: TOKİ Ankara Kusunlar yoksul grubu konutları örneği, [Affordable housing provision: A case study of TOKI Ankara Kusunlar low-income housing] Ankara Araşttrmaları Dergisi [Journal of Ankara Studies], 3(1), 42-53.

Atkinson, R. (1998). Displacement from gentrification: How big a problem? Radical Statistics, 69, 21-24.

Atkinson, R. (2000). Measuring gentrification and displacement in greater London. Urban Studies, 37, 149-165.

Ayata, S. (1989). Toplumsal çevre olarak gecekondu ve apartman [The gecekondu and the flat as social environments]. Toplum ve Bilim, (46/47), 101-127.

Belediye Kanunu'na Bâzı Maddeler Eklenmesine Dair Kanun. [Kanun no: 5656]. (1950, 31 Mart). T.C. Resmî Gazete, 7471. Accessed on June 14, 2016 at https://www.tbmm.gov.tr/tutanaklar/KANUNLAR_KARARLAR/kanuntbmmc032/kanuntbm mc032/kanuntbmmc03205656.pdf

Brown-Saracino, J. (2009). A neighborhood that never changes: Gentrification, social preservation, and the search for authenticity. Chicago: University of Chicago Press.

Butler, T. (1997). Gentrification and the middle classes. Sydney: Ashgate.

Butler, T. (2007). For gentrification? Environment and Planning A, 39, 162-181.

Caulfield, J. (1994). City Form and everyday life: Toronto's gentrification and critical social practice. Toronto: University of Toronto Press.

Clark. E. (1988). The rent gap and the transformation of the built environment: Case studies in Malmo 1860-1985. Geografiska Annaler, 70B, 241-254.

Clark, E. (1991). Rent gaps and value gaps: Complementary or contradictory. In J. van Weesep and S. Musterd (Eds.) Urban housing for the better off: Gentrification in Europe (pp. 17-29). Utrecht: Stedelijke Netwerken.
Davidson, M. (2008). Spoiled mixture: Where does state-led 'positive' gentrification end? Urban Studies, 45(12), 2385-2405.

De Soto, H. (2001). The mystery of capital. London: BlackSwan.

Değişen Çankaya, GEÇAK RP leaflet. (1996). Ankara: Municipality of Çankaya District,

Erder, S. (1996). İstanbul'a bir kent kondu: Ümraniye [A city sprouted in İstanbul: Ümraniye]. İstanbul: İletişim Yayinlari.

Erder, S. (1997). Kentsel gerilim [Urban tension]. Istanbul: Uğur Mumcu Araştırmacı Gazetecilik Vakfı.

Ergun, C., and Gul, H. (2009). Toplumcu belediyecilik ve kent kapılarını sermayeye açan anahtar olarak kentsel dönüşüm [Social progressive municipal governments and urban renewals as the key that unlocks the city gates to capital]. In I. Kamalak and H. Gul (Eds.). Yerel yönetimlerde sosyal demokrasi, toplumcu belediyecilik: teorik yaklaşımlar, Türkiye uygulamaları (pp. 295-332). İstanbul: SODEV Yayınları.

Erman, T. (1998a). Kentteki kırsal kökenli göçmenlerin yaşamında gecekondu ve apartman [The squatter housing and the flat in the life of the rural migrants in the city]. In 75 yılda değişen kent ve mimarlık (pp. 317-324). İstanbul: Tarih Vakfi.

Erman, T. (1998b). Becoming urban or remaining rural: the views of Turkish rural-to-urban migrants of the integration question. International Journal of Middle East Studies, 30, 541-561.

Erman, T. (2001). The politics of squatter (gecekondu) studies in Turkey: the changing representations of rural migrants in the academic discourse, Urban Studies, 38(7), 983-1002.

Erman, T. (2016). Mış gibi site: Ankara'da bir TOKI - gecekondu dönüşüm sitesi. [As if site (Building complex): A TOKI in Ankara-squatter settlement transformation site] İstanbul: İletişim.

Ezema, I. C., Opoko, P. A. Oluwatayo, A. A. (2016) Urban regeneration through state-led, new-build gentrification in LagosInner City, Nigeria. International Journal of Applied Environmental Sciences 11(1), 135-146.

Freeman, L. (2006). There goes the hood: Views of gentrification from the ground up. Philadelphia, PA: Temple University Press.

Gecekondu Kanunu. [Kanun No: 775]. (1966, 30 Temmuz). T.C. Resmî Gazete, 12362, 2626. Accessed on June 14, 2016 at http://www.mevzuat.gov.tr/MevzuatMetin/1.5.775.pdf

Gecekonduya 'yerinde 1slah' modeli [An in situ gecekondu rehabilitation model] (1994, 13 Şubat) Ekonomist, 5, 44.

GEÇAK Projesi çerçevesinde gecekondular davul-zurna eşliğinde $y_{\imath} k_{\imath} l d \imath$ [Within the framework of the GEÇAK Project gecekondus were demolished with joy] [news] (n.d.). Accessed on 23.03.2012 at http://www.portakal.com/ahaber-GEÇAKprojesi-cercevesinde-gecekondular-davul-zurna-esligindeyikildi-66379.html 
GEÇAK Projesi Raporu [GEÇAK Project Report] (1995). Ankara: Çankaya Belediyesi İmar Müdürlügü [Municipality of Çankaya District].

Gentrification, displacement and the role of public investment: A literature review. (2015). Federal Reserve Bank of San Francisco Community Development Investment Center. Accessed on 05.02.2016 at http://www.frbsf.org/communitydevelopment/files/wp2015-05.pdf

The gentrification reader. (2008). New York, London: Routledge.

Giddens, A. (1998). The third way: The renewal of social democracy. Cambridge: Polity Press.

Giddens, A. (2000). The third way and its critics. Cambridge: Polity Press.

Gilbert, A. Gugler, J. (1989). Cities poverty and development. New York: Oxford University Press.

Glass, R. L. (1964). London: Aspects of change. London: MacGibbon \& Kee.

Gottdiener, M. (1988). Beyond the Marxian political economy: The trinity formula and the analysis of space. In The social production of space. Texas: The Union of Texas Press.

Gökçe, B., Acar, F., Ayata, A., Kasapoğlu, A., Özer, İ., \& Uygun, H. (1993). Gecekondularda ailelerarasi geleneksel dayanışmanın çağdaş organizasyonlara dönüşümü [The transformation of traditional inter-family solidarity into contemporary organizations]. Ankara: T.C. Başbakanlık, Kadın ve Sosyal Hizmetler Müsteşarlığı Yayını.

Grier, G. and E. Grier. (1978). Urban displacement: A reconnaissance. Bethesda, Maryland: The Grier Partnership.

Güneş Ayata, A. (1986). Migrants and natives: Urban bases of social conflict. In E. Jeremy (Ed.) Migrants, workers and social order (pp. 234-247). London: ASA.

Güzey, Ö. (2006). Understanding the logic of gentrification in different geographies: A comparison of five regeneration projects in Ankara, Turkey. paper presented to 42nd ISoCaRP Congress, İstanbul.

Hackworth, J. (2002). Postrecession gentrification in New York city, Urban Affairs Review. 37(6), 815-843.

Hackworth, J., and Smith, N. (2001). The changing state of gentrification, Tijdschrift Voor Economische En Sociale Geografie. 92(4), 464-477.

Hammel. D. J. (1999a). Re-establishing the rent gap: An alternative view of capitalized land rent. Urban Studies, 36(8), 1283-1293.

Hammel, D. J. (1999b). Gentrification and land rent: A historical view of the rent gap in Minneapolis, Urban Geography, 20(2), 116-145.

Hamnett, C. (1984). Gentrification and residential location theory: A Review and assessment. In D. Herbert, R.J. Johnston (Eds.). Geography and the urban environment: Progress in research and applications (pp. 283-319). New York: Wiley.
Hamnett, C. (2003). Gentrification and the middle-class remaking of London, 1961-2001. Urban Studies, 40, 2401-2426.

Harvey, D. (1998). Globalization and the body, in INURA, Possible urban worlds: Urban strategies at the end of the twentieth century (pp.26-39). Basel: Birkhauser.

Harvey, D. (2006) Spaces of global capitalism: Towards a theory of uneven geographical development. London and New York: Verso.

Huse, T. (2014). Everyday life in the gentrifying city: on displacement, ethnic privileging, and the right to stay put. Farnham: Ashgate.

İmar ve Gecekondu Mevzuatına Aykırı Yapılara Uygulanacak Bazı İșlemler ve 6785 Sayılı İmar Kanunu'nun Bir Maddesinin Değiştirilmesi Hakkında Kanun [Kanun no: 2981]. (1984, 8 Mart). T.C. Resmî Gazete, 18335, 36. Accessed on June 14, 2016 at http://www.mevzuat.gov.tr/MevzuatMetin/1.5.2981.doc

İslam, T. (2005). Outside the core: Gentrification in Istanbul. In R. Atkinson and Bridge, G. (Eds.). Gentrification in a global context: The new urban colonialism. London: Routledge.

İstanbul'da soylulaştırma: Eski kentin yeni sahipleri [Gentrification in Istanbul: The New Owners of the Old City]. (2006). İstanbul: Bilgi Üniversitesi Yayınları.

Jelinek, C. (2011). State-led gentrification and relocation in Budapest. Unpublished master's thesis, Central European Universty, Budapest.

Keil, R. (1997) Globalization makes states: Perspectives of local governance in the age of world city. Review of International Political Economy, 5(4), 616-646.

Keil, R. (2000). The third way urbanism: opportunity or dead end? Alternatives, 25(2), 247-267.

Keleş, R. (1987) Yerel yönetimler ve konut. Ankara Üniversitesi Siyasal Bilgiler Fakültesi Dergisi, 42(1), 1-13. Accessed on June 14, 2016 at http://www.politics.ankara.edu.tr/dergi/ pdf/42/1/rusenkeles.pdf

Kuzu, A. (1997). Urban redevelopment approaches for the squatter areas within a changing context of urban planning case study Ankara: GEÇAK Urban Redevelopment Project. Unpublished master's thesis, METU, Ankara.

Lees, L. (2015) Tone Huse: Everyday life in the gentrifying city: On displacement, ethnic privileging, and the right to stay put. Journal of Housing and the Built Environment, 30, 705-706.

Legates, R. and Hartman, C. (1986). The anatomy of displacement in the United States. In N. Smith and Williams, P. (Eds.). Gentrification of the City (pp. 178-203). London: Allen and Unwin.

Lemanski C. (2014). Hybrid gentrification in South Africa: Theorising across southern and northern cities. Urban Studies, 51(14), 2943-2960. 
Ley, D. (1994). Gentrification and the politics of the new middle class. Environment and planning D: Society and space. 12(1), 53-74.

Ley, D. (1996). The new middle class and the remaking of the central city. Oxford; New York: Oxford University Press.

Ley, D. (2003). Artists, aestheticisation and the field of gentrification. Urban Studies, 40(12), 2527-2544.

Malusardi, F. and Occhipinti, G. (2003). Informal settlements upgrading: the gecekondus in Ankara. Paper presented to the $39^{\text {th }}$ ISoCaRP Congress, Cairo.

Marcuse, P. (1986). Abandonment, gentrification, and displacement: The linkages in New York City. In N. Smith and P. Williams (Eds.) Gentrification of the City, (pp. 153-77). NewYork: Routledge.

Marcuse, P. (1997). Dual city: Muddy metaphor for a quartered city. International Journal of Urban and Regional Research, 13, 697-708.

Newman, S. J. and Owen, M. S. (1982). Residential displacement: Extent, nature, and effects. Journal of Social Issues,38(3), 135-148.

Niedt C. (2006). Gentrification and the grassroots: Popular support in the Revanchist suburb. Journal of Urban Affairs, 28(2), 99-120.

Pattillo, M. (2008). Black on the block: The politics of race and class in the city. Chicago: University of Chicago Press.

Peker, M. (1996). Internal migration and the marginal sector. In E. Kahveci, Sugur, N. and Nichols, T. (Eds.) Work and occupation in modern Turkey (pp. 7-37). New York: Man Sell.

Redfern, P. A. (2003). What makes gentrification 'gentrification'? Urban Studies, 40(12), 2351-2366.

Rittersberger Tılıç, H. (1997) Farklı kuşak göçmenlerin kente uyumları: Ankara'da iki gecekondu örneği [Adaptations of different generations of migrants to urban life: Two gecekon$d u$ cases in Ankara] paper presented to 3. Ulusal Nüfusbilim Konferans1 [the $3^{\text {rd }}$ National Congress of Demography] Ankara.

Sandercock, L. (1998). The death of radical planning: Radical praxis for a postmodern age. In Douglass, M., and Friedman, J. (Eds.) Cities for citizens-planning and the rise of the civil society in a global age (pp. 163-184). Chichester: Wiley.

Sargin, G. A. (2004). Displaced memories or the architecture of forgetting and remembrance. Environment and Planning D: Society and Space, 22, 659-680.

Satterthwaite, D. (2009). Getting land for housing; what strategies work for low-income groups? Environment \& Urbanization, 21(2), 299-307.

Şengül, H. T. (2003). On the trajectory of urbanisation in Turkey: An attempt at periodisation. IDPR, 25(2), 153-168.

Şengül, H. T. (2009). Kentsel çelişki ve siyaset [Urban contradiction and politics]. Ankara: Imge Kitabevi.
Senyapili, T. (1981). Gecekondu: Çevre işçilerin mekanı [Gecekondu: the space of workers from the periphery]. Ankara: ODTÜ Mimarlık Fakültesi.

Senyapili, T. (2004). Charting the voyage of squatter housing in urban spatial Quadruped. European Journal of Turkish Studies, Thematic Issue (1). Accessed on 20.06.2012 at http:// www.ejts.org/document142.html

Slater, T. (2004). What is gentrification. Accessed on 1.06.2012 at http://members.lycos.co.uk/gentrification/whatisgent.html

Slater, T. (2009). Missing Marcuse: On gentrification and displacement. City, 13(2/3), 293-311.

Slater, T., Curran, W. and Lees, L. (2004). Guest editorial. Environment and Planning A, 36, 1141-1150.

Smith, C. Duncan, B. Reid, L. (1988). Disinvestment, reinvestment and the economic frontier live in gentrifying neighborhoods. Paper presented to the Housing Policy and Innovation Conference, Amsterdam, June, 1988.

Smith, N. (1979). Toward a theory of gentrification A back to the city movement by capital, not people. Journal of the American Planning Association, 45(4), 538-548.

Smith, N. (1987). Of yuppies and housing: gentrification, social restructuring and the urban dream. Environment and Planning D: Society and Space, 5, 151-172.

Smith, N. (1996). The new urban frontier: Gentrification and the Revanchist City. London and New York: Routledge.

Smith, N. (2002). Gentrification generalized: from local anomaly to urban regeneration as global urban strategy. Paper presented to the conference, Upward Neighborhood Trajectories: Gentrification in a New Century, Glasgow, 26-27 September.

TOKI. (2012). Accessed on 27.06.2012 at https://www.toki.gov. tr/en/background.html

Türker Devecigil, P. (2009). Kentsel dönüşümün aktörleri ve sürdürülebilirlik: Dikmen Vadisi örneği [The actors of urban transformation and sustainability: The Dikmen Valley example] In Gecekondu, dönüşüm, kent, Tansı Şenyapılı'ya Armağan, [Gecekondu, Transformation, City, A Tribute to Tansı Şenyapılı]. Ankara: ODTÜ Mimarlık Fakültesi Yayınları.

Ulufer, B. Çırak, H. (1997). Bir gecekondu semti olan Kırkkonaklar [Kirkkonaklar: a gecekondu community]. Unpublished term paper. Ankara: METU, Department of Sociology.

Uzun, N. C. (2003). The impact of urban renewal and gentrification on urban fabric: three cases in Turkey. Tijdschriftvoor Economische en Sociale Geographic, 94(3), 363-375.

Uzun, N. (2008). Ankara'da kentsel dönüşüm [Urban renewal in Ankara]. Paper presented to Ankara Kent Sorunları Sempozyumu [Ankara Urban Issues Symposium] Accessed on (20.06.2012) at http://www.tmmob.org.tr/resimler/ ekler/7cdfd23373b17c6_ek.pdf 
Varlı Görk, R. (2002). Gecekondu bölgeleri ve yerinde islah projelerine sosyolojik bir bakış: Gecekondu sorunu ve yoksulluk üzerine görgül bir çalışma. Paper presented to the 26. Dünya Şehircilik Günü Kolokyumu [26 $6^{\text {th }}$ World Urbanization Day Colloquium] . Gazi Üniversitesi Şehir Bölge Planlaması Bölümü, Ankara.

Varlı Görk, R. (2005) Gentrification in Ankara following the rehabilitation plan(s). Paper Presented to the 22nd World Congress of Architecture, UIA 2005, İstanbul

Wharton, J. L. (2008) Gentrification: The new colonialism in the modern era. Forum on public policy. Accessed on 08.02.2016 at http://forumonpublicpolicy.com/summer08papers/archivesummer08/wharton.pdf
Wyly E. (2015). Gentrification on the planetary urban frontier: The evolution of Turner's noösphere. Urban Studies, 52(14), 2515-2550

Wyly, E., Newman, K., Schafran, A. and Lee, E. (2010). Displacing New York. Environment and Planning A, 42, 2602-2623.

Zukin, S.(1982). Loft living: Culture and capital in urban change. Baltimore: Johns Hopkins University Press.

Zukin, S. (1987). Gentrification: Culture and capital in the urban core. Annual Review of Sociology, 13(1), 129-47.

Zukin, S. (2009). Naked city: The death and life of authentic urban places. Oxford University Press. 